\title{
O Último Carro: \\ uma viagem de trem com João das Neves nos anos 1960/70
}

\author{
Kátia Paranhos* \\ Universidade Federal de Uberlândia-UFU, Minas Gerais, Brasil \\ E-mail: akparanhos@uol.com.br
}

\section{Resumo}

Por vezes condenada como escapista, outras vezes incensada como ferramenta de libertação revolucionária, a arte, de modo geral, continua sendo um tema candente tanto na academia como fora dela. Este trabalho aborda as múltiplas faces de João das Neves, autor de $O$ último carro, espetáculo que deveria ser apresentado pelo Grupo Opinião em 1968 e só encontrou lugar e tempo propício para sua encenação em 1976. O eixo de análise aqui proposto consiste, de certa forma, em tentar iluminar diferentes maneiras de se fazer teatro no Brasil, no caso, pelas bordas. Afinal, o diretor, recentemente falecido, se notabilizou pelo engajamento político ou "legítimo", como lembra Eric Hobsbawm noutro contexto, dando vazão à capacidade de lançar ideias e desafios, em plena ditadura militar, propondo então indagações que ecoam até os dias de hoje.

\section{Palavras-chave}

João das Neves. Engajamento.1968. Dramaturgia
Abstract

Sometimes condemned as escapist, other times praised as a tool for revolutionary liberation, art generally remains a hot topic within academia as well as elsewhere.This paper deals with João das Neves' various aspects. He was the author of $O$ último carro, which Grupo Opinião would have staged in 1968, but they only found the right place and time to do so in 1976. The analysis we propose here tries to illuminate different ways of making theater in Brazil, in this case, from the edges inward. Indeed, the late director became known for his political or "legitimate" engagement, as Eric Hobsbawm puts it in a different context, raising ideas and challenges under the Brazilian military dictatorship, issues that have lost nothing of their contemporary relevance.

Keywords

João das Neves. Engagement. 1968. Dramaturgy.

\footnotetext{
* Doutora em História Social pela Universidade Estadual de Campinas (Unicamp). Professora do Instituto de História e do Programa de Pós-graduação em História da Universidade Federal de Uberlândia/UFU. Bolsista produtividade em pesquisa do CNPq e do Programa Pesquisador Mineiro, da Fapemig. Autora, entre outros livros, de História, teatro e política. São Paulo: Boitempo, 2012 e Cena, dramaturgia e arquitetura: instalações, encenações e espaços sociais. Rio de Janeiro: 7Letras, 2014.
} 
O teatro político constitui tema de destaque na obra de João das Neves. Basta lembrar um dos seus mais importantes trabalhos, O último carro ou As 14 estações, metáfora do Brasil em um trem desgovernado, montado pelo Grupo Opinião em 1976. A peça foi concebida e escrita entre 1961 e 1962 e 1964-1965 sendo refeita em 1967 por ocasião do $1^{\circ}$ Seminário Carioca de Dramaturgia, da qual foi vencedora. ${ }^{1} \mathrm{O}$ enredo foi urdido em meio às viagens de trem que o autor fazia quando dirigia o Teatro Artur Azevedo, em Campo Grande, Rio de Janeiro. Todos os seus personagens, segundo ele, foram seus companheiros nas viagens diárias de trem pela Central do Brasil. No texto a ação se dá quase inteiramente nos vagões de um trem, onde, numa simples viagem pelos subúrbios cariocas, mendigos, operários e personagens comuns do cotidiano revelam, entre uma parada e outra, seus dramas particulares. Entretanto, de acordo com João das Neves, não existia consenso na montagem naquele momento:

[...] não foi endossada, pois o grupo tinha a visão como um todo de que ela precisaria ser modificada, quer dizer, a segunda parte, onde a peça sai do enfoque naturalista da realidade e parte para o realismo fantástico, era rejeitada pelo grupo.

[...]

[..] fiquei querendo montar a peça, mas não tinha recursos nem possibilidades. E, além disso, porque a censura não permitiria. (NEVES, 1984, p. 57).

Em 1968, em meio às divergências pessoais, o Opinião produziu Jornada de um imbecil até o entendimento, de Plínio Marcos, direção de João das Neves e Dr. Getúlio, sua vida e sua glória, de Dias Gomes e Ferreira Gullar, direção de José Renato. O último carro ou As 14

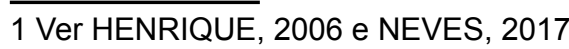

estações só encontrou lugar e tempo propício para sua encenação em 1976. João das Neves relembra:

Ao retomar [...] o texto e realizar a sua montagem é como se nós, do Grupo Opinião, retomássemos muitos dos propósitos que motivaram a criação de nosso grupo e fizeram com que ele sobrevivesse, apesar de tudo. [...] assistimos à dissolução do Teatro lpanema, à nossa própria dissolução e recomposição, assistimos a variadas tentativas de amesquinhamento do teatro brasileiro e à sua admirável teimosia, único ponto de identificação, talvez, entre o teatro e o povo do qual deveria se originar e ao qual deveria se dirigir. (NEVES, 1976, p. 5). ${ }^{2}$

\section{Teatro e política}

O autor, tradutor, ator, diretor e iluminador João das Neves, nascido no Rio de Janeiro em 1935, participou de importantes grupos de teatro, como o do Centro Popular de Cultura (CPC) da União Nacional dos Estudantes (UNE), o CPC-UNE/Setor Teatro (RJ), o Opinião (RJ) e o Poronga (AC). Sua entrada no CPC ocorreu quando da montagem da peça $A$ grande estiagem (1958), de Isaac Gondim Filho. O grupo de João das Neves, denominado Os Duendes (1959/1963), foi expulso do Teatro Artur Azevedo e acusado de comunista pelo governo de Carlos Lacerda. Logo, a inclusão do diretor no CPC se deu à medida que a repressão da administração estadual chegava cada vez mais perto dos grupos periféricos. Nesse episódio,

2 Depois da montagem de Antígona, em 1969, o Grupo Opinião, afogado em dívidas, dissolve-se. João das Neves, o único que não aceita tal decisão, decide continuar sozinho e parte em busca de novos parceiros. O teatro inclusive será alugado, em alguns momentos, para jovens iniciantes e o próprio diretor passa a comandar espetáculos fora do eixo Rio-São Paulo. Ver NEVES, 1984, p. 55-59 e KÜHNER e ROCHA, 2001. 
o grupo encontrou solidariedade no CPC, cuja ideia principal era difundir os valores nacionais e acontecimentos políticos daquele momento por meio de representações cênicas que eram levadas aos mais variados espaços e públicos. No depoimento concedido a Jalusa Barcellos, João das Neves relembra aquele período:

Nós tínhamos um grupo de teatro amador. Eu era não só diretor desse grupo, como também dirigia o Teatro Artur Azevedo, em Campo Grande. Quem me levou para lá foi a Maria Clara Machado, que ocupava no governo estadual um cargo que seria hoje a presidência da Funarj, mais ou menos. Eu me transferi para Campo Grande com o meu grupo, que se chamava Os Duendes, e fazíamos de tudo um pouco: teatro adulto, infantil, teatro de fantoches, biblioteca infantil etc... Também circulávamos com os espetáculos. Íamos para associações, praças públicas... O interessante desse nosso trabalho é que ele tinha uma certa relação com o CPC. Além de ser musicado - teatro de fantoches, por exemplo - , as peças eram escritas dentro do trem, aos domingos. Nós sempre tínhamos peças novas. Escrevíamos todos os domingos. Inclusive porque era o único tempo que tínhamos para escrever. $\mathrm{O}$ trem levava umas duas horas para chegar a Campo Grande e nesse trajeto a gente organizava tudo. O grupo original era formado por Pichin Plá, Paulo Nolasco, Nilo Parente e mais a Virgínia Valli, que organizava o teatro de fantoches. [...] Como não havia muitos grupos amadores no Rio de Janeiro, nosso trabalho adquiriu certa importância até que, por ocasião da montagem de $A$ grande estiagem, nós chegamos num domingo ao teatro e o nosso cenário estava todo quebrado. O rapaz que cuidava do teatro nos disse que a ordem era não deixar a gente entrar. Claro que o governo era do Carlos Lacerda. [...] A grande estiagem era uma peça sobre a seca e, é obvio, o tratamento tinha que ser político (NEVES apud BARCELLOS, 1994, p. 259-206).
Assim, em 1963, João das Neves encontrou abrigo no CPC/UNE:

A partir de determinado momento, passei a dirigir o teatro de rua do CPC. A carreta ficou comigo. Quer dizer, não só a carreta como todos os eventos de rua. Os shows, os esquetes, tudo o que se fazia na rua. Aliás, esse é um trabalho do qual muito me orgulho. Porque se ouve muito determinado tipo de crítica dizendo que o teatro de rua do CPC era maniqueísta, simplista etc... Ora, nós sempre tivemos clareza de que aquele teatro tinha a sua especificidade. $O$ teatro de rua não é um teatro em que você possa ter nuances psicológicas, ter meias medidas. Ele tem uma estética própria, que não é nem inferior nem superior a outro tipo de estética, mas ele tem a sua, específica, que aliás o CPC desenvolveu largamente. De qualquer forma, com o passar do tempo, nós também reavaliamos essa questão do teatro de agitação e propaganda, do teatro de rua, e começamos a pensar em outras possibilidades teatrais a serem exploradas. Inclusive a nossa inclusão enquanto artistas no próprio mercado de trabalho, com um teatro de esquerda (NEVES apud BARCELLOS, 1994, p. 262).

De certa maneira, pode-se afirmar que o CPC trabalhava com Os Duendes, no Teatro Artur Azevedo, como teatro de fantoches e de rua, no entanto, utilizava e encenava textos baseados nos acontecimentos políticos do momento; os integrantes escreviam roteiros e iam para a rua representar. Essa atividade serviu muito a João das Neves como pesquisa de linguagem de autor, de ator e diretor, uma vez que, como autor, por exemplo, tinha experiência apenas com textos para crianças. Paulatinamente, adquiriu agilidade de tomar um tema e transformá-lo rapidamente em um esquete, o que se tornou uma das características marcantes de sua produção textual: a rusticidade, o imediatismo simples e ao mesmo tempo 
sofisticado do teatro de rua e a agilidade em escrever um texto sobre determinado tema. A esse respeito, afirma o diretor:

[...] o nosso trabalho era muito direto, em cima do acontecimento, como uma reportagem crítica das coisas que estavam acontecendo. Privilegiávamos as formas teatrais populares mais diretas porque o nosso teatro era feito nas ruas, praças, sacadas de faculdades, nos subúrbios, nas roças, ou em caminhão volante para as montagens mais ambiciosas; fazíamos teatro em qualquer lugar. Usávamos a forma de representar dos palhaços, dos bobos, o reizado, bumba-meu-boi, a commedia dell'arte, o mamulengo etc. Os fatos aconteciam, imediatamente estabelecíamos um roteiro crítico e íamos pra rua. Existia todo um processo de elaboração: escrevíamos, montávamos e íamos pra rua representar. As montagens eram muito rápidas, tipo teatro de guerrilha, no sentido de transmitir nossa mensagem (NEVES apud MICHALSKI, 1980, p. 43). ${ }^{3}$

Em um debate realizado pelos integrantes da Companhia do Latão, em 2010, João das Neves, que se assume como um "artista engajado" e "comprometido com a realidade do seu país" (NEVES, 2010), recorda os sentidos do fazer teatral nos tempos do CPC:

[...] nós tínhamos vontade de ter um palco móvel para sair pelos subúrbios, levando o espetáculo. Esse caminhão foi um projeto interessante, mas era um elefante branco. Era difícil de carregar como o diabo. Na época não se usava materiais leves como se tem hoje, era tudo feito na madeira. Mas ele andou pelo Brasil inteiro, até a extinção do CPC. Nós estreamos no Largo do Machado, com uma versão de Revolução na América do Sul dirigida por mim. É claro que eu tinha, e tenho pretensões estéticas, e o Carlos Estevam não concordava com essas

3 Sobre a trajetória de João das Neves, ver NEVES, 1987a e 2017. pretensões estéticas. O teatro para ele era um pretexto. Para mim não era um pretexto, pelo contrário. Eu estou falando isso um pouco para dizer que ambiente existia no CPC, isso me parece muito importante. O CPC era um espaço democrático de ampla discussão da cultura brasileira, com várias correntes, mas que estavam ali para fazer alguma coisa que julgassem fundamental (NEVES, 2010). ${ }^{4}$

Imediatamente após o golpe militar de 1964, um grupo de artistas ligados ao CPC (posto na ilegalidade), reuniu-se com o intuito de criar um foco de resistência e de protesto àquela situação. Foi então produzido o show musical Opinião, com Zé Kéti, João do Vale e Nara Leão (depois substituída por Maria Bethânia), cabendo a direção a Augusto Boal. O espetáculo, apresentado no Rio de Janeiro em 11 de dezembro de 1964, no Teatro Super Shopping Center, marcou o nascimento do grupo, batizado com o nome da peça, bem como o do próprio teatro, que viria a se chamar Opinião. Os integrantes do núcleo permanente eram Oduvaldo Vianna Filho (o Vianninha), Paulo Pontes, Armando Costa, João das Neves, Ferreira Gullar, Thereza Aragão, Denoy de Oliveira e Pichin Plá.

Desde a sua fundação o grupo privilegia a arte popular, abrindo espaço para shows com compositores das escolas de samba cariocas, não apenas influindo na mudança de gosto do público, mas também, por intermédio dessa

\footnotetext{
4 Para Ferreira Gullar, "o grande erro do CPC foi dizer que a qualidade literária era secundária, que a função do escritor é fazer de sua literatura instrumento de conscientização política e atingir as massas, porque se você for sofisticado, se fizer uma literatura, um teatro, uma poesia sofisticada, você não vai atingir as massas. Então, propunha fazer uma coisa de baixa qualidade para atingir as massas. [...] Nós nem fizemos boa literatura durante o CPC, nem bom teatro, nem atingimos as massas. Então, nós sacrificamos os valores estéticos em nome de uma tarefa política que não se realizou porque era uma coisa inviável" (GULLAR apud RIDENTI, 2000, p. 111).
} 
mescla de espaços, facilitando a disseminação da cultura periférica aos centros de divulgação. Assembleias, reuniões e demais manifestações de protesto da categoria teatral faziam do Opinião seu epicentro nos primeiros anos após o golpe militar. Para João das $\mathrm{Ne}-$ ves, que dirigiu o Opinião por dezesseis anos, o trabalho

[...] era fundamentalmente político e, assim pesquisar formas nos interessava - e interessa - muito. [...] A busca em arte não é apenas estética - ela é estética e ética ao mesmo tempo. Eu coloco no que faço tudo o que eu sou, tudo o que penso do mundo, tudo o que imagino da possibilidade de transformar o mundo, de transformar as pessoas. Acredito na possibilidade da arte para transformar (NEVES, 1987a, p. 20-21).

É importante salientar que o grupo focaliza suas ações no teatro de protesto, de resistência, e também se caracteriza por ser um centro de estudos e de difusão da dramaturgia nacional e popular. Afinado com essas propostas artísticas e ideológicas, o diretor privilegia a montagem de textos, tanto nacionais quanto estrangeiros, que sirvam de enfoque para a situação política do Brasil nos anos da ditadura militar, tais como: A saída, onde fica a saída? (em 1967), de Armando Costa, Antônio Carlos Fontoura e Ferreira Gullar; Jornada de um imbecil até o entendimento (1968), de Plínio Marcos; Antígona (1969), de Sófocles, numa tradução de Ferreira Gullar; $A$ ponte sobre $O$ pântano (1971), de Aldomar Conrado, e O último carro (1976) Mural mulher (1979) e Café da manhã (1980) de João das Neves. ${ }^{5}$

5 Em O quintal, concebida em 1978 e encenada em 1981 em Londrina/PR, João das Neves apresenta como enredo a invasão do prédio da UNE pelos militares, no dia $1^{\circ}$ de abril de 1964, e as consequências dessa ação para os oito personagens que lá se encontravam (Ver NEVES in: ESCOBAR et al,
A estreia de Jornada de um imbecil até o entendimento ocorreu em 13 de junho de 1968. No elenco, entre outros, Ari Fontoura, Milton Gonçalves, Denoy de Oliveira, Jorge Cândido e José Wilker. João das Neves enfatiza:

Plínio Marcos abandona aquele teatro-fotografia para buscar novos rumos. [...] A peça é intencionalmente esquemática, dando margem ao diretor de recriação. A direção e os atores trabalharam juntos na discussão social de cada um dos personagens e como resultado chegamos a uma imensa improvisação (NEVES, 1968, p. 15).

Em setembro de 1969, o crítico Sábato Magaldi anotou:

O autor, que denuncia com violência as mazelas sociais, cede lugar aqui ao moralista que procura corrigir os erros dos costumes sem perder a mira, mas caçoando também dos próprios recursos teatrais. O diálogo mantém sempre a objetividade e a virulência do autor de Dois perdidos numa noite suja e Navalha na carne, e ao mesmo tempo adquire a quase amenidade de quem prefere não agredir, mas aliciar pelo riso. No conjunto, Jornada situa-se em nível inferior aos melhores textos de Plínio, com a vantagem de provar que ele não é um dramaturgo esgotado num estilo e tem talento e versatilidade para experimentar outras formas.

O diretor João das Neves compreendeu muito bem o problema que lhe é proposto pela peça e deu a melhor solução possível. Ỏ espetáculo passa-se num circo, à maneira do Auto da compadecida de Ariano Suassuna e aí o feitio de farsa ganha um relevo natural e uma linguagem muito adequada (MAGALDI, 2014, p. 97). ${ }^{6}$

1978, p. 111-122).

6 Em O teatro sob pressão, Yan Michalski observa que o " 'maldito' Plínio Marcos, pouco acrescentou ao seu acervo anterior através da sua Jornada de um imbecil até o entendimento, montada pelo Opinião [...]" (MICHALSKI, 1985, p. 37). Para Edélcio Mostaço, "[...] tomando o picadeiro de circo e suas personagens como espaço cênico - afastando-se das 
Tempo depois, nos anos 1980, o diretor (re) avalia os sentidos do seu trabalho:

[...] esta peça, para mim, foi um marco fundamental; porque é uma peça escrita em cima da perna. Não é uma peça acabada; [...] no espetáculo, aproveitei tudo o que acumulara como experiência: do circo, que aprendera na infância; do teatro de rua; do CPC. Enfim, joguei tudo em cima dessa peça; e misturei. Era uma loucura, porque eu misturava todos os gêneros.

Peguei o Vergara, que era um artista plástico e, juntos, bolamos um cenário muito interessante. Nós trabalhávamos em arena e, nela, o chão é fundamental. Então, enchemos o chão com espuma de níveis diferentes, de modo que a movimentação dos atores era determinada não só por uma marcação básica, mas também pelas reações que o chão dava a eles. O chão impulsionava os atores e, a cada dia, os colocava surpreendentemente em situações novas. [...] a peça ganhou dimensão teatral com a encenação através do trabalho dos atores, do meu trabalho e do trabalho do Vergara. Quem lia a peça, ficava com a impressão de que o texto não tinha valor. Mas, levada à cena, através dessa encenação [...] ela adquiriu outra dimensão. [...] A dimensão, evidentemente, estava na peça. O problema era descobri-la. E foi o que acho que nós fizemos (NEVES, 1987a, p. 18-19). ${ }^{7}$ criaturas marginalizadas que tão apropriadamente enfocara em seus textos iniciais - Plínio tenta aqui tornar didático o processo capitalista da mais-valia, empregando a linguagem das ruas, tão sua conhecida. O resultado, todavia, é apenas sofrível" (MOSTAÇO, 2016, p. 132-133).

7 "Plínio Marcos dá um giro de $180^{\circ}$, lança-se a um novo caminho, sem temer os erros a que esse caminho possa conduzi-lo... É possível que, além do diálogo enxuto, da exata medida entre tensão e desafogo, da aguda capacidade de observação, muito pouco reste do Plínio Marcos que o público se habituou a ver e aplaudir... Seu trabalho pressupõe riqueza de colorido, alegria violenta, enorme capacidade de improvisação dos atores, características só encontradas no descaramento interpretativo dos palhaços de circo ou na vigorosa commedia dell'arte italiana" (NEVES apud KÜHNER e ROCHA, 2001, p. 98).
Outra referência básica que merece destaque é a utilização da dramaturgia e dos métodos propostos por Bertolt Brecht. Recorto um trecho que me parece bastante sugestivo:

Quero falar sobre o que Brecht representa para nós. Participei nos idos de 63/64, do Centro Popular de Cultura (CPC) e depois fui um dos fundadores do Grupo Opinião do Rio de Janeiro. Nas preocupações iniciais, no ideário do Centro Popular de Cultura, estava a luta pela transformação da sociedade que acreditávamos que pudesse ser realizada, inclusive através do teatro, usando-o como instrumento dessa transformação. A revelação de Brecht para nós, as discussões sobre Brecht naqueles momentos, foram extremamente ricas porque nos revelaram que o teatro político tinha outros caminhos que não apenas o agit-prop, que não apenas a agitação e propaganda. Brecht nos mostrou que o teatro, por ser político, não excluía a possibilidade do aprofundamento, quer nos sentimentos, quer no mecanismo da existência do homem em sociedade. Ele não precisava ser tão imediato para ter sua contundência, sua eficácia política comprovada. Essa primeira constatação veio através do estudo de Brecht. Embora estivéssemos longe de aplicar as teorias de Brecht, diretamente, em nosso trabalho, seu estudo foi para nós de extrema importância, para que pudéssemos fazer uma avaliação crítica do trabalho que estávamos realizando nas ruas, nos sindicatos: o teatro de agit-prop que nós fazíamos no CPC e seus possíveis desdobramentos. Depois do golpe de 1964, um grupo de pessoas que saíra do CPC veio a formar o grupo Opinião e este grupo aprofundou um tipo de dramaturgia e de encenação que, se não tinha Brecht como ponto de partida, deve, no entanto, à sua reflexão muito da qualidade alcançada [...].

Na história de um grupo como o Opinião e na história de grupos como o Arena e o Oficina, a passagem por Brecht, o conhecimento dele, a leitura ou a realização de suas peças, a discussão de suas teorias, o entrar em contato com seu humor, com um novo 
tipo de abordagem teatral, com uma nova relação ator-espectador, são de suma importância (NEVES apud BADER, 1987b, p. 242 e 244).

As experiências do teatro operário, do Arena, dos Centros Populares de Cultura (CPCs), do Oficina e do Opinião em busca do político e do popular carrearam um amplo movimento cultural que envolveu grupos, diretores, autores e elencos - conjunto que sofreu um violento revés com o golpe militar e, em particular, após ser decretado o Al-5 em 1968. ${ }^{8}$ A partir de então, para numerosos grupos, fazer um teatro popular significava assumir uma posição de rebeldia frente ao teatro comercial - o teatrão - e ao regime político; e até se pode detectar algumas expressões para essa forma de agitação, como "teatro alternativo" e/ou "teatro independente". 9

No que se refere ao campo da cultura, em especial no teatro no Brasil do pós-1964, interessa salientar que, enquanto a maioria dos artistas estava profissionalmente vinculada à indústria cultural, outros buscavam provisoriamente o exílio e alguns ainda tentavam uma resistência à modernização conservadora da sociedade, inclusive ao avanço da indústria cultural. Estes procuravam se articular inclusive com os chamados novos movimentos sociais que, aos poucos, organizavam-se mesmo com a repressão (sobretudo em alguns sindicatos e comunidades de bairro) e muitas vezes em atividades associadas com setores de esquerda da igreja católica. Em Santo André, por exemplo, foi fundado em 1968 o Grupo de Teatro

8 Sobre os espetáculos encenados em 1968, em especial Roda viva, ver MICHALSKI, 1985 e MOSTAÇO, 2016.

90 termo "independente" origina-se de países da Europa e da América Latina, onde a organização teatral se dá em moldes diferentes dos nacionais. Ver DOSIO, 2003. da Cidade (GTC). Com outros grupos teatrais montados na periferia paulistana (tais como Núcleo Expressão de Osasco, Teatro-Circo Alegria dos Pobres, Núcleo Independente, Teatro União e Olho Vivo, Grupo Ferramenta de Teatro e Grupo de Teatro Forja), o GTC constituiu o "teatro da militância" - na expressão de Silvana Garcia (2004).

Apesar da censura e da ditadura militar, o teatro brasileiro, de uma maneira geral, nos anos 1960 e 1970, continuava dando sinais de uma produção crescente e voltada, na maioria das vezes, para o campo político. Cabe realçar, a atuação dos dramaturgos Jorge Andrade, Gianfrancesco Guarnieri, Augusto Boal, Dias Gomes, Ferreira Gullar, Oduvaldo Vianna Filho, Plínio Marcos, Carlos Queiroz Telles. Merecem também registro produções teatrais que traziam consigo a insatisfação com a ordem existente, como as do Teatro Universitário (TUCA) PUC-SP, TUSP/USP, TEMA/Teatro Mackenzie) e dos grupos Teatro Jovem (RJ), Teatro Carioca de Arte (RJ), Dzi Croquettes (RJ), Asdrúbal Trouxe o Trombone (RJ), Teatro de Arena de Porto Alegre/TAPA (RS), Grita (CE), Imbuaça (SE), Sociedade Teatro dos Novos (BA), Teatro Livre da Bahia (BA), Oi Nóis Aqui Traveiz (RS). No início da década de 1980, novas companhias despontavam no cenário ainda governado pelos militares, como o Tá na Rua (RJ) e o Galpão (MG). ${ }^{10}$

\section{- João das Neves num trem de subúrbio}

Em 1976, como mencionado anteriormente, o Opinião levou à cena carioca $O$ último car-

10 Sobre outras linguagens teatrais ver PACHECO in: MELLO (org.).,1986, p. 95-105; FERNANDES, 2000; PARANHOS in: CARREIRA e LIMA (orgs.)., 2009, p. 93-117 e VAZ, 2011. 
ro ou As 14 estações de João das Neves. A segunda parte do título, ou As 14 estações, traz uma possível referência às 14 estações da Via-Sacra ou Via Crucis. ${ }^{11}$ Por sinal, vale mencionar que por conta desse trabalho ele foi premiado com o Molière de melhor direção e recebeu o prêmio Brasília de melhor autor naquele ano e prêmio Mambembe de melhor diretor em 1977. ${ }^{12}$ O último carro ou As 14 estações

é um texto em que o povo brasileiro é agente e paciente, autor e intérprete de si mesmo. Seu universo é o universo dos subúrbios cariocas, onde vivem mais de $65 \%$ da população útil do Rio de Janeiro. É o universo dos que precisam se utilizar diariamente dos trens suburbanos. Neles perdem $1 / 3$ dos seus dias, $1 / 3$ das suas vidas. É o universo dos "emparedados" pelos vagões da Central ou Leopoldina ou qualquer via férrea por este Brasil afora. É um Universo trágico, regido pelos deuses cegos de um Olimpo sem grandeza, num mundo que não produz mais herói porque o heroísmo está encravado na luta cotidiana pela sobrevivência de toda a população de uma cidade, de um país, de um mundo (NEVES, 1976, p. 5).

Para Carlos Nelson Coutinho (apud NEVES, 1976, s/p.) autor do prefácio de O último carro, há que se destacar a importância da orientação brechtiana da montagem, sobretudo na ausência de um conflito individualizado central. A construção narrativa é essencialmente épica, com grande número de personagens

11 Este título está presente, por exemplo, n $5^{\mathrm{a}}$ edição do texto, publicada em 1976 e editada pelo próprio grupo, juntamente com os nomes dos atores do espetáculo no Rio de Janeiro e em São Paulo. As 14 estações baseiam-se em passagem dos Evangelhos ou em tradições populares e são imagens distribuídas no interior das igrejas ou em trajetos ao ar livre onde os fiéis contemplam e retratam as imagens do sacrifício de Cristo, de sua condenação, passando pela crucificação até ser deposto no sepulcro.

12 Ao todo foram dezenove prêmios entre 1976 e 1979. populares lutando pela sobrevivência na sociedade capitalista. Nesse sentido, a preocupação básica é "a discussão concreta de problemas concretos do povo brasileiro". Tanto O último carro quanto Gota d'água, de Chico Buarque e Paulo Pontes,

ligam-se uma tradição fortemente abalada em 1964 e, mais ainda, em 1968, porém jamais inteiramente soterrada: a tradição do 'teatro político' [...] a presença simultânea dessas duas peças nos palcos brasileiros, aliada a manifestações similares em outros campos da arte e da literatura, é um sintoma de que a época do 'vazio cultural' está sendo progressivamente superada" (COUTINHO apud NEVES, 1976, s/p.).

Em cena, então, "pequenos dramas", como o do mendigo Zé, bêbado, maltrapilho, que sobrevive de esmolas e que por elas briga até o final da cena com sua companheira, Zefa, uma mulher tão abandonada quanto ele ${ }^{13}$. De repente, o trem começa a correr sem rumo, sem maquinista, sem freios. Todos abruptamente saem do torpor de suas rotinas e se integram em uma viagem radical, limiar, definidora de posições e atitudes, causadora de desespero, pânico, perdas e também de uma intensa luta por uma saída do trem desgovernado. Deolindo, um operário, sugere desprender o último carro do restante da composição. Uma criança é jogada acidentalmente do trem. Um marginal comete suicídio pulando do trem. Um beato anuncia o juízo final e conclama todos para desistirem de qualquer tipo de saída, senão aquela da oração e do arrependimento de seus pecados. Trava-se uma luta entre os dois grupos. Deolindo é morto. Uma prostituta, que acaba de ser violentada, ampara a cabeça

13 "Zé - A coisa que mais prezo no mundo é a minha liberdade. (Canta) Liberdade! Liberdade! Abre as asas sobre nós" (NEVES, 1976, p. 20). 
de Deolindo em seus joelhos. As pessoas do último carro tentam desvencilhar o vagão; os demais rezam. Um enorme estrondo domina a cena. O último carro lentamente para. Imagens de desastre de trem, corpos mutilados. Diante das imagens, todos velam o corpo de Deolindo. Um coro de mulheres se dirige ao público. Mulheres viúvas, mulheres sem pais, sem filhos.

Parcela considerável dos críticos destaca que um dos méritos que consagrou esta encenação reside no espaço cênico do espetáculo. Inédita em nossos palcos, a disposição espacial de $O$ último carro inaugura um novo contato com os espectadores - ao dispor o cenário do trem em volta da platéia e posicionando o público em bancos que faziam parte dos vagões - contribuindo, desta forma, para o desenvolvimento da encenação e do teatro brasileiro. Em março de 1976, o crítico Yan Michalski, comenta:

Por mais generosas que sejam a concepção geral do texto e a sua colaboração em termos de técnica dramatúrgica [...] a leitura da peça mal permitia prever um espetáculo da dimensão, da complexidade e da clareza do que está no Opinião. A direção de João das Neves, de um fôlego infinitamente superior a tudo o que ele fizera até então, aparece como um coroamento, surpreendentemente brilhante mas coerente, de 20 anos de tentativas e estudos. O primeiro passo para esse acerto é o ousado e feliz espaço cênico criado pelo cenógrafo Germano Blum, que construiu ao longo das paredes do teatro quatro perfeitos interiores de vagões de um trem, combinados com passarelas que se transformam, por simples mudança de iluminação, em plataformas das estações. A cenografia cumpre perfeitamente a sua tríplice missão: a de ambientar convincentemente a ação, a de envolver emocionalmente a plateia e a de proporcionar margem para acontecimentos políticos que se desenrolam sem perda de visibilidade nem de clareza expositiva. O diretor utilizou com mão de mestre, modificando permanentemente os agrupamentos de cerca de 40 personagens de acordo com as sugestões do clima no momento, colocando-os em composições sugestivas, explorando expressivamente as fontes luminosas e sonoras da própria cenografia [...] num dos mais emocionantes e sustentados crescendos de emoção ultimamente vistos num teatro carioca. A exemplar trilha sonora de Rufo Herrera, partindo de elementos puramente realistas para se transformar-se aos poucos num poderoso elemento criador de clima, tornou-se, ao lado da cenografia, um decisivo aliado da direção para a obtenção da sufocante tensão na parte final do espetáculo.

\section{[...]}

Num mesmo prédio, a poucos passos de distância, estão simultaneamente em cena Gota d' água e O último carro, dois excelentes espetáculos visceralmente brasileiros, que atribuem à massa popular o papel de protagonista (MICHALSKI, 2004, p. 248-249). ${ }^{14}$

Conforme Maria Helena Kühner e Helena Rocha, O último carro representa um "salto qualitativo" no trabalho do Grupo Opinião. As autoras assim analisam a peça:

Os laivos de populismo [...] ou mesmo suas contradições [...], vão dar lugar a um texto/espetáculo em que a linguagem busca, e efetiva, uma relação com o pensamento que informa e o contexto ou realidade em que se acha inserida. Ou seja, ao transportar a cena para

14 Em 1985, Yan Michalski assinala, mais uma vez, a importância do espetáculo: "Numa fantástica ambientação cenográfica de Germano Blum, que dá ao espectador a exata sensação de estar viajando num trem de subúrbio, desenrola-se uma série de pequenos mas terríveis dramas cotidianos vividos pelos habitantes da periferia que dependem desse meio de transporte. [...] João das Neves, ao mostrar a dura realidade desse submundo e ao cercá-la de generoso calor humano, criou o equivalente brasileiro de Ralé, a obra-prima de Gorki" (MICHALSKI, 1985, p. 67). Entre 1975 e 1976 a censura liberou três peças que colocavam em cena as camadas populares e seu sofrido dia-a-dia: Gota d'água, de Chico Buarque e Paulo Pontes, Muro de arrimo, de Carlos Queiroz Telles, e O último carro. Ver FARIA, 1998, p. 163-174. 
um trem da Central do Brasil que leva e traz as populações suburbanas em seu cotidiano, a peça focaliza as aspirações, necessidades, valores, formas de percepção e visão de mundo que as chamadas "camadas populares" têm da própria condição. Os mendigos, a prostituta, os operários indo para o trabalho, os malandros, o beato, o menino vendedor de amendoim ou o vendedor de cocada são figuras apanhadas em situações corriqueiras de seu cotidiano, com dificuldades e busca de soluções para os problemas que surgem [...], até um acontecimento colocá-los diante de um problema maior e geral, que afeta e ameaça sua própria vida: a grande metáfora do trem des-governado exigindo dos passageiros uma atitude eficaz - que vai ser encontrada através da reunião no "último carro", dos que querem deixar aquele rumo fatal, "desligando-se" para outro rumo.

Visão terna, que exibe a via-crúcis da população oprimida - o subtítulo As 14 estações o assinala - mas nem por isso menos crítica, mostrando relações de dominação ou exploração no interior da própria classe [...]. Os valores conservadores culturalmente introjetados [...]; o fatalismo que leva à inação; o "esperar pra ver como é que fica"; o misticismo cego [...], são aspectos importantes a serem expostos. Mudar as situações concretas é também mudar o ponto de vista, o lugar da fala, [...] ter uma opinião, uma opção [...] (KÜHNER e ROCHA, 2001, p. 102-103, grifos das autoras).

Segundo João das Neves:

Se vocês pegarem o texto e lerem, verão que ele utiliza uma série de linguagens diferentes. Ora utiliza uma linguagem cotidiana de subúrbio, de gírias, ora passa para a linguagem deliberadamente poética e metrificada. As falas do beato que atravessam a peça, por exemplo, são todas feitas em cima de transformações de versos bíblicos. [...].

O que quero dizer é que, com essa peça, continuei toda a pesquisa de linguagem que vinha fazendo até então. A pesquisa não parou ao nível da es- crita, multiplicou-se na hora da encenação e, também, na própria relação, que me pareceu extremamente nova, entre a peça e o espectador (NEVES, 1987a p. 30-32).

Para o diretor João das Neves, o texto teatral é, antes de mais nada, uma "obra de arte" que suscita "inúmeras emoções, frequentemente contraditórias". Nesse sentido, o romance e o conto são obras completas, acabadas, quando se oferecem à leitura. No texto dramatúrgico, ao contrário, a leitura é apenas o início de um processo que só se fechará com a encenação do espetáculo:

as idéias expressas por um romancista ou contista não poderão ser alteradas pela interpretação do leitor. A forma acabada ali está. Por onde quer que caminhe a minha imaginação, ela estará realizando um caminho único e solitário. O ponto de referência de cada leitor será sempre o próprio romance ou o conto. Já no teatro, no texto teatral, melhor dizendo, aquelas idéias poderão ser profundamente afetadas pela interpretação que se faça delas. Isto porque o texto teatral necessita sempre de mediadores entre o mero leitor e o espectador. Estes mediadores são os intérpretes: atores, diretores, cenógrafos, figurinistas, iluminadores, enfim, os realizadores do espetáculo teatral, que, partindo do texto, irão se apresentar, em uma das inúmeras formas finais possíveis aos prováveis espectadores (NEVES, 1997, p. 12-13).

Em 1998, Sábato Magaldi, ao fazer um balanço sobre o teatro, elenca quatro momentos importantes na cenografia brasileira: a renovação estética do grupo Os Comediantes, do Teatro Brasileiro de Comédia/TBC, do Arena e a produção de $O$ último carro ou As 14 estações:

Sob a direção [de João das Neves] o cenógrafo Germano Blum construiu 
um espaço em que o trem do subúrbio carioca se espraiava num retângulo que envolvia a platéia, e alguns espectadores postavam-se em bancos que pareciam fazer parte dos vagões. A composição se deslocava, simbólica e vertiginosamente, sem maquinista, até que muitos passageiros conseguiram separar o último carro. Um estrondo indicava o acidente fatal para os outros vagões, enquanto o que se desligou, diminuindo aos poucos a velocidade, conseguia parar. Significado da metáfora: sobrevive quem domina o próprio destino, sem aceitar passivamente o desastre provocado pela falta de direção. Um desejo otimista de resistência, durante a ditadura (MAGALDI, 2003, 59-60).

De acordo com João das Neves, as cenografias de O cemitério dos automóveis (1968) e de $O$ balcão (1969), do argentino Victor García, foram referências importantes na composição cênica do texto:

A gente sempre se ajuda um ao outro. [...] havia todas as experiências anteriores: a do Hélio Eichbauer, com o cenário de Antígona; aquele chão que eu tinha feito com o Vergara. E também [os] dois espetáculos do [...] Victor García, este sim, um diretor de vanguarda, um diretor de espetáculos fenomenal e também um cenógrafo fantástico. Quando vi seu trabalho, exclamei: "É isso aí; esta é a idéia básica do cenário da minha peça!".

Quando comuniquei ao Germano, ele se entusiasmou logo pela idéia. Então, fizemos uma verdadeira revolução em termos cenográficos. Viramos a arena de ponta-cabeça, pois colocamos o público no palco e o espetáculo em volta do público. Não só em volta, como acima do público; e parte desse público ficava, também dentro do espetáculo, dentro dos próprios vagões. Além disso, tratamos o espaço do teatro como o espaço da Central do Brasil. O público entrava e tinha de atravessar o cenário para chegar às cadeiras. Entrava-se por uma catraca da Central do Brasil, que dava ao público a sensação de gado que as pessoas têm, ao entrar por essas catracas. [...] Colocamos bancos para o público. Não cadeiras, bancos; bancos sem encosto, profundamente desconfortáveis. Não havia o palco frontal, o espetáculo desenrolava-se em volta (NEVES, 1987a, p. 27).

Os anos 1960, em especial, trariam novos e ricos rumos para o teatro, desde o Living Theater, seus rituais e hapennings, às teorias do polaco Jerzy Grotowsky, autor de uma corrente mais despojada, dando larga importância à expressão do corpo cênico, o chamado "teatro pobre", passando pelos angry young men da Inglaterra até Peter Brook e sua peculiar noção de espaço teatral e da nova relação palco/público. Esses movimentos, observados em parte pelo mundo ocidental, correspondiam aos anseios de criadores, artistas e público jovem que não se reconheciam mais no teatro tradicional, questionando-o e buscando outras e mais desafiantes alternativas - transformando, amiúde, o teatro num laboratório, permeável às diferentes experiências e fusões com elementos cênicos de outras culturas. ${ }^{15}$ Nesse sentido, podemos afirmar que se evidenciava o aparecimento de novos públicos, novas temáticas, novas linguagens e a dinamização de canais não convencionais de comuni-

15 Para Marília Gomes Henrique, "a busca de uma nova prática artística do teatro político dos anos de 1960, especialmente aquela comprometida com o desenvolvimento de imagens que contribuíssem para a revelação da realidade social, constitui um passo importante para a consolidação de novas poéticas, que se diferenciavam da forma tradicional em que era produzido e realizado o espetáculo. [...] Nesta época, a encenação deixa de ser um apêndice do texto e passa a incorporar, apesar das características e propostas de cada grupo, o ponto de vista do encenador. A partir de então, as encenações exploram de diferentes modos o espaço cênico. Espetáculos como Cemitério de automóveis (1968) ou, mais radicalmente, O balcão (1969), encenados por Vítor Garcia, e Os Lusíadas (1972) inauguram novas possibilidades espaciais de diálogo com o espectador" (HENRIQUE, 2006, p. 70- 71). Sobre ambiente criativo ao longo dos anos 1960, nas artes de um modo geral, ver também MOSTAÇO, 2016, p. 131-150. 
cação que transgrediam as normas do sistema ${ }^{16}$, apesar de - como afirmou certa vez Eric Hobsbawm, numa passagem bastante elucidativa -,

nossas gerações terem sofrido do capitalismo uma lavagem cerebral para acreditar que a vida é o que o dinheiro pode comprar [...]. Há mesmo mais do que o desespero quanto a uma sociedade incapaz de dar a seus membros o que eles precisam, uma sociedade que força cada indivíduo ou cada grupo a cuidar de si próprio e não se importar com o resto. Já foi dito: "Dentro de cada trabalhador existe um ser humano tentando se libertar" (HOBSBAWM, 1987, p. 388).

O último carro retoma tanto o problema social quanto o existencial numa dimensão histórica dos dramas enfrentados pelos trabaIhadores na sociedade capitalista. Em cena: a luta pela sobrevivência, a solidão nas grandes metrópoles, o trabalho precarizado, o desemprego, a situação de abandono no campo, o individualismo e o narcisismo dos próprios operários, a circularidade entre o "bem" e "mal”, a exposição dos preconceitos sociais, a busca pelo "caminho fácil" do crime, o desânimo, a crueldade, a violência. Aliás, é interessante perceber como a dramaturgia de Plínio Marcos está muito próxima da obra de João das Neves: ambas percorrem da existência miserável dos sujeitos despossuídos que habitam o mundo do trabalho à cidade moderna, lugar dos sonhos e pesadelos, da industrialização moderna, do desemprego e da pobreza. ${ }^{17}$

16 Sobre "teatro de guerrilha" e "teatro do trabalhador" ver DAVIS, 1968 e FEBROT,1968.

17 Os "tipos" plinianos subvertem até certo tipo de teatro engajado em voga nos anos de 1960 e 1970, pois não veiculam, em regra, uma mensagem otimista ou positiva quanto à possibilidade de se ter alguma esperança de mudança social. $\mathrm{O}$ que importa é subsistir, seja como for: sem solidariedade de classe, sem confiança no próximo. Seus personagens se debatem num mundo que não oferece vislumbre de redenção;
Cabe realçar que o espetáculo foi visto por mais de 200 mil pessoas entre Rio e São Paulo, provocando uma mudança significativa na preparação de atores, na utilização do espaço cênico, e atraindo, inclusive, os olhares de um público mais diversificado e dos críticos em geral. Em outubro de 1977, Sábato Magaldi registra:

O último carro, em cartaz no Palácio da Bienal, no Parque lbirapuera, é um dos mais felizes exemplos de como uma peça, direção, desempenho e espaço cênico podem amalgamar-se, para produzir um grande espetáculo. [...] $\mathrm{O}$ teatro torna-se arte, na sua plenitude, pela magia que se processa em realizações como essa. [...] A virtude maior de encenação de João das Neves prende-se à organicidade do espaço cênico. Tanto no Teatro Opinião do Rio como na sala especialmente construída na Bienal, o trem de subúrbio carioca espraia-se no retângulo que envolve a platéia, e alguns espectadores postam-se em bancos que parecem fazer parte dos vagões. Com esse recurso, as numerosas cenas se desenvolvem em locais próprios, numa continuidade e numa flexibilidade que representam um permanente estímulo para o público. Sente-se a materialidade do teatro, no que ela tem de mais legítimo e fascinante. [...] $O$ último carro foi justamente considerado o melhor espetáculo da última temporada carioca. Transferindo-se para São Paulo, a antitragédia inscreve-se na mesma linha inovadora que preside a XIV Bienal e se distingue, até o momento, como a melhor montagem do ano e uma das mais perfeitas até hoje realizadas no Brasil" (MAGALDI, 2014, p. 510-512).

Vale conferir também a impressão do escritor Milton Hatoum:

estão envolvidos em situações mesquinhas e sórdidas, em que a luta pela sobrevivência e pelo dinheiro não tem dignidade; via de regra, enveredam para a marginalidade mais violenta a fim de atingir seus objetivos. Ver PARANHOS, 2012a e $2012 b$. 
A peça de João das Neves, que saiu de cartaz em São Paulo na semana passada, dia 14, tem como protagonista central o povo - e já foi vencedora de vários prêmios de dramaturgia, tendo sido aplaudida pela crítica especializada. Esta antitragédia brasileira, como o próprio autor a denomina, é uma prova de que nosso teatro continua vivo e atuante, traçando um painel crítico da nossa realidade sem recorrer a um tom dogmático, maniqueísta ou panfletário (HATOUM, 1978, p. 72). ${ }^{18}$

Em O último carro, o foco de análise está centrado nas relações de poder estabelecidas confusamente num emaranhado de seres ignorados pelos "cidadãos contribuintes", fazendo emergir uma fauna de alcaguetes, prostitutas, homossexuais, cafetões e cafetinas, operários, donas de casas, policiais corruptos: seres jogados em cena sem nenhuma cortina de fumaça. Na peça, avultam como temas a solidão e a decadência humana, o círculo vicioso da tortura mútua e a absoluta falta de sentido nas vidas degradadas, a sexualidade e os padrões de comportamento dominantes, o beco sem saída da miséria e a violência, a superexploração do trabalho humano e a morte prematura como horizonte permanente. Sobressaem, portanto, sujeitos sociais distintos, marcados pela tragédia individual e coletiva.

O público se confundia com os passageiros do trem, ultrapassando os limites de meros espectadores reflexivos. Passavam a integrar 0 elenco e a construir novas cenas, com diferentes discursos que faziam a intertextualidade do já dramatizado. Por sinal, ao se referir aos dife-

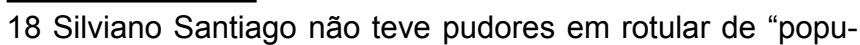
listas" os textos dramatúrgicos Gota d'água, O último carro e Ponto de partida, de Gianfrancesco Guarnieri. Tal rótulo recaía sobre a ineficácia do teatro como veículo para se tratar de temas como a luta de classes e a realidade nacional, tendo em vista a mediação da bilheteria que permite, ou nega, o acesso ao conteúdo, por mais revolucionário que ele seja. Ver SANTIAGO,1982, p. 28 rentes gêneros literários, Benoît Denis salienta que o teatro é um "lugar" importante do engajamento; é exatamente aquele que propicia as formas mais diretas entre escritor e público: "através da representação teatral, as relações entre o autor e o público se estabelecem como num tempo real, num tipo de imediatidade de troca, um pouco ao modo pelo qual um orador galvaniza a sua audiência ou a engaja na causa que defende" (DENIS, 2002, p. 83).

Arte e política se misturam e se contaminam, negociando continuamente a resistência e a gestão daquilo que é em relação ao que pode vir a ser, pondo em tensão o que está "dentro" e o que está "fora" do sistema instituído. João das Neves, por meio da literatura dramática, funde diferentes expressões, imagens, metáforas, alegorias e outros elementos que, em conjunto, compõem um cenário significativo de articulações de um modo de pensar e agir, uma visão do mundo. Esse resultado reitera a noção de que as formas e produções culturais se criam e se recriam na trama das relações sociais, da produção e reprodução de toda a sociedade e de suas partes constitutivas. Afinal,

as histórias nunca ocorrem no vácuo,
é claro. Nós nos engajamos no tempo
e no espaço, dentro de uma sociedade
em específico e de uma cultura maior.
Os contextos de criação e recepção
são tanto materiais, públicos e eco-
nômicos quanto culturais, pessoais e
estéticos (HUTCHEON, 2011, p. 54). ${ }^{19}$

Os passageiros dessa viagem - homens e mulheres - estão sentados nos vagões de um trem, onde histórias simples, de pessoas simples, são desfiadas. A narração das vivên-

19 Sobre o tema do engajamento, ver SCHWARZ, 1999, p. 172-177 e PARANHOS, 2012a. 
cias populares aparece encarnada em vários pequenos conflitos dramáticos, desde o que retrata o casal de mendigos no início da peça até aquele do qual são protagonistas Beto e Mariinha, passando pelo episódio da família da estação, pela discussão dos marginais.

Há alguma identificação entre aquelas pessoas e os espectadores? "Ele era tão diverso do senhor, moço. $\mathrm{E}$, no entanto, igual". O ruído das rodas do trem vai dominando o ambiente e como que repetindo em sua cadência rítmica a última pergunta dirigida aos espectadores. "Qual a estação mais próxima? A mesma de ontem?" A peça não termina (NEVES, 1997, p. 63).

Em 1984 - após passagens por Salvador (com a criação do Opinião-Núcleo 2 1972/1975) ${ }^{20}$ e pela Alemanha (1978/1980) e a dissolução do Opinião em $1980^{21}$ - , João das Neves se mudou para Rio Branco onde, com atores amadores vindos da periferia, fundou o Grupo Poronga:

Convidaram-me para dar um curso, eu fiquei lá durante um mês [...], acabei me identificando com um grupo de pessoas de lá [...].

[...] fizemos alguns espetáculos, e eu pude desenvolver uma série de coisas que tinha vontade de fazer no Rio de Janeiro e não podia. Com o Poronga nós pudemos colocar em prática algu-

20 "Realizamos em Salvador um trabalho que parecia um pouco com o que a gente tinha feito no Opinião e tentava parecer-se um pouco com o que fazíamos no CPC. Procurávamos abranger todas as áreas da atividade cultural, e não apenas o teatro. [...] Levamos a Salvador os melhores profissionais de teatro infantil de então para discutir o teatro infantil, para fazer oficinas [...]. Fazíamos, também, festivais de música. Enfim, era uma atividade muito grande" ( NEVES, 1987a, p. 24).

21 Apesar das montagens de Mural mulher, em 1979, e Café da manhã, em 1980, e também dos protestos e manifestos, com centenas de assinaturas, o teatro seria vendido. Os jornais chegaram a registrar a importância do Grupo "que foi um encontro de cabeças pensantes, uma ideologia, um movimento de vanguarda e de resistência". Na ocasião, João das $\mathrm{Ne}$ ves declarou: "o Opinião é coisa que não se vende" (KÜHNER e ROCHA, 2001, p. 194). mas idéias, tendo aquela realidade que nos cercava como base para nossas pesquisas e nosso trabalho. A partir de então, acho que nunca mais trabaIhei em um palco convencional, em um espaço de palco italiano. Nosso teatro era um teatro de arena. Mas mesmo o espaço de arena era um motivo de discussão. Meus trabalhos no Teatro Opinião foram sempre trabalhos que, entre outras coisas, discutiam o espaço cênico. A nossa arena nunca funcionou basicamente como arena, com as pessoas em volta: eu sempre fiz invenções de espaço, sempre discuti a linguagem desse espaço de arena que tínhamos e isso gerou alguns espetáculos bastante intrigantes (NEVES apud GARCIA, 2002, p. 159-160).

Na década de 1990, João das Neves fixou residência em Belo Horizonte e continuou desenvolvendo inúmeros projetos artísticos. Circulou pelo país por diferentes espaços teatrais. Em 2008, ele afirmou que nunca deixou que a peça $O$ último carro "fosse montada por grupos profissionais, só por amadores, porque não se presta a eventuais operações comerciais, como diminuição de personagens" (NEVES, apud WAJNBERG, Daniel Schenker, 2008, p. 33).

Em 2015, o diretor e sua trajetória foram tema de uma grande exposição realizada no Itaú Cultural, em São Paulo. Com curadoria do próprio João das Neves e de sua mulher, a cantora Titane, a "Ocupação João das Neves" dividiu-se em quatro eixos que percorreram os seus 60 anos dedicados à arte, e ajudaram a compreender a sua carreira de artista engajado e militante: "Anos de chumbo", "Lugares", "Identidades" e "Festa". Escreveu ainda peças e concebeu personagens que iluminaram questões e dilemas vivenciados por indígenas, negros, mulheres, sertanejos, prostitutas e representantes do movimento LGBT, em obras como Tributo a Chico Mendes (1989), Primei- 
ras estórias (1992), Pedro Páramo (2001), Besouro cordão de ouro (2006) Galanga - Chico Rei (2010), As polacas (2010), A Santinha e os congadeiros, Aos nossos filhos, Madame Satã (2015) e Bonecas quebradas (2016) - esta última focada na questão do feminicídio na América Latina.

João das Neves morreu em decorrência de uma metástase óssea, na sua casa, em Belo Horizonte, aos 84 anos, no dia 24 de agosto de 2018, cercado do carinho da sua mulher e de seus amigos. Difícil esquecer o trem de 1968, a viagem, homens e mulheres sem destino, sujeitos itinerantes em ação. "O último carro [...] retoma em 76 um fio perdido há algum tempo. Não me parece [...] que o texto tenha perdido atualidade. Muito ao contrário. O silêncio forçado só fez aumentar o rumor subterrâneo nas gargantas do nosso povo" (NEVES, 1976, p. 5). Fecham-se as cortinas.

Referências

BARCELLOS, Jalusa (org.). CPC da UNE: uma história de paixão e consciência. Rio de Janeiro: Nova Fronteira, 1994.

DAVIS, Ron. G. O teatro de guerrilha. Revista Civilização Brasileira, n. 18, Rio de Janeiro, 1968, p. 199-206.

DENIS, Benoit. Literatura e engajamento: de Pascal a Sartre. Bauru: Edusc, 2002.

DOSIO, Célia. El Payró. Buenos Aires: Emecé, 2003.
FARIA, José Roberto. Teatro e política no Brasil: os anos 70. In: Teatro na estante. Cotia: Ateliê Editorial, 1998, p. 163-174.

FEBROT, Luiz Izrael. Teatro do trabalhador e teatro de massas. Revista Civilização Brasileira, n. 18, Rio de Janeiro, 1968, p. 207-220.

FERNANDES, Sílvia. Grupos teatrais - anos 70. Campinas: Editora da Unicamp, 2000.

GARCIA, Silvana (org.). Odisséia do teatro brasileiro. São Paulo: Editora Senac São Paulo, 2002.

GARCIA, Silvana. Teatro da militância. 2. ed. São Paulo: Perspectiva, 2004.

HATOUM, Milton. Teatro para o povo? João sabe como é. Isto É, São Paulo, junho, 1978, p. 70-73.

HENRIQUE, Marília Gomes. O realismo crítico-encantatório de João das Neves. Dissertação (Mestrado em Artes) - IA-Unicamp, Campinas, 2006.

HOBSBAWM, Eric J. A década de 70: sindicalismo sem sindicalistas?. In: Mundos do trabaIho: novos estudos sobre história operária. Rio de Janeiro: Paz e Terra, 1987, p. 379-389.

HUTCHEON, Linda. Uma teoria da adaptação. Florianópolis: Ed. da UFSC, 2011.

KÜHNER, Maria Helena e ROCHA, Helena. Opinião: para ter opinião. Rio de Janeiro: Relumé Dumará/Prefeitura, 2001. 
MAGALDI, Sábato. O moderno teatro brasileiro. In: Depois do espetáculo. São Paulo: Perspectiva, 2003, p. 55-65.

Amor ao teatro. São Paulo:

Edições Sesc São Paulo, 2014.

MICHALSKI, Yan. O teatro sob pressão: uma frente de resistência. Rio de Janeiro: Jorge Zahar, 1985.

Reflexões sobre o teatro brasileiro no século XX. Rio de Janeiro: Funarte, 2004.

MOSTAÇO, Edélcio. Teatro e política: Arena, Oficina Opinião. 2. ed. São Paulo: Annablume, 2016.

NEVES, João das. A farsa, um novo gênero de Plínio Marcos. Jornal do Brasil, Caderno B, Rio de Janeiro, 10. Jun. 1968, p. 15-16.

O último carro. 5. ed. Rio de Janeiro: Grupo Opinião, 1976.

O quintal. In: ESCOBAR, Carlos Henrique et al. Feira brasileira de Opinião. São Paulo: Global, 1978, p. 111-122.

Uma tentativa sincera de trabalho com a cultura popular. In: MICHALSKI, Yan (org.). Ensaio teatro. Rio de Janeiro: Edições Muro, 1980, p. 41-44.

Grupo Opinião: a trajetória de uma rebeldia cultural. Problemas, São Paulo, n. 9,1984 , p. 55-59.
Ciclo de palestras sobre o teatro brasileiro 5. Rio de Janeiro: Inacen, 1987a.

O papel de Brecht no teatro brasileiro: uma avaliação. In: BADER, Wolfgang (org.). Brecht no Brasil: experiências e influências. Rio de Janeiro: Paz e Terra, 1987b, p.

A análise do texto teatral. Rio de Janeiro: Editora Europa, 1997.

A hora do teatro épico. Traulito, n. 3, 2010. Disponível em <http://www.traulito. com.br/?p=808>. Acesso em 20 jun. 2016.

Programa Ribalta - Série Diretores/João das Neves. Exibido em 3 de abril de 2017. Disponível em <https://www.youtube. com/watch?v=SaploDC-H9U>. Acesso em 11 jul. 2018.

PACHECO, Tânia. Teatro alternativo em 70: a luz no final do túnel. In: MELLO, Maria Amélia (org.). Vinte anos de resistência. Rio de Janeiro: Espaço e Tempo, 1986, p. 95-105.

PARANHOS, Kátia Rodrigues. Textos, espaços e sujeitos sociais: outras linguagens na cena teatral brasileira. In: CARREIRA, André e LIMA, Evelyn Furquim Werneck (orgs.). Estudos teatrais. Florianópolis: Ed. da Udesc, 2009, p. 93117.

Pelas bordas: história e teatro na obra de João das Neves. in: PARANHOS, Kátia Rodrigues (org.). História, teatro e política. São Paulo: Boitempo, 2012a, p. 135-156. 
Plínio Marcos e

João das Neves: caminhos cruzados, trajetórias, arte e engajamento no Brasil pós-1964. In:

AVELAR, Alexandre de Sá e SCMIDT, Benito Bisso (orgs.). Grafia da vida: reflexões e experiências com a escrita biográfica. São Paulo: Letra e Voz, 2012b, p. 169-188

RIDENTI, Marcelo. Em busca do povo brasileiro. Rio de Janeiro: Record, 2000.

SANTIAGO, Silviano. Vale quanto pesa: ensaios sobre questões político-culturais. Rio de Janeiro: Paz e Terra, 1982.

SCHWARZ, Roberto. Nunca fomos tão engajados. In: Sequências brasileiras. São Paulo: Companhia das Letras, 1999, p. 172-177.

VAZ, Toninho. Solar da fossa. Rio de Janeiro: Casa da Palavra, 2011.

WAJNBERG, Daniel Schenker. Os muitos Brasis de João das Neves. Revista de Teatro/Sbat, n. 520, Rio de Janeiro, 2008, p. 32-33.

Recebido: 08/11/2018 Aprovado: 28/12/2018 